\title{
Rising impact, fast review: Annual Report October 1997 to September 1998
}

We are pleased to see Thorax back as the respiratory journal with the highest impact factor in Europe (2.3, ISSN Statistics 1998). This undoubtedly reflects the high quality of submitted papers. Our review system is still working extremely quickly. The median time to first decision was 56 days for full papers and 24 days for short papers, which compares favourably with last year's figures and is a marked improvement on previous years (table 1). ${ }^{1}$ We believe that this decision time is by far the most rapid of any respiratory journal. Our policy of only accepting the best papers ${ }^{2}$ is reflected again in the acceptance rate which, for papers submitted in the year up to 30 September 1998, will be somewhere midway between $15 \%$ and $45 \%$ (table 2 ). The number of original papers is down slightly (table 3 ), ${ }^{1-3}$ with the UK and Western Europe being the main source of our manuscripts (table 4). ${ }^{1-3}$ Thorax is an international journal and we are keen to increase the number of papers that we publish from other parts of the world. In keeping with this approach we have expanded the international advisory board in an attempt to make it more representative of worldwide respiratory medicine. We would therefore encourage contributors from North, Central and South America, Africa, Eastern Europe, Asia, and Australasia to think about Thorax for their work.

Last year saw the publication of important guidelines on the management of respiratory disesases including tuberculosis ${ }^{4}$ and lung cancer. ${ }^{5}$ In conjunction with guidelines on COPD, ${ }^{6}$ asthma, ${ }^{7}$ and nebulisers ${ }^{8}$ which were published in 1997, these serve as a useful concise source of current wisdom in respiratory medicine. 1998 saw the end of the highly successful Science Matters series ${ }^{9}$ with continuation of the review series on passive smoking ${ }^{10}$ and

Table 1 Median time to first decision (days)

\begin{tabular}{llll}
\hline & $1995 / 6$ & $1996 / 7$ & $1997 / 8$ \\
\hline Full papers & 74 & 44.5 & 56 \\
Short papers & 82 & 38 & 24 \\
\hline
\end{tabular}

Table 2 Decision on papers submitted 1997/8 as at 30 September 1998

\begin{tabular}{lcrrl}
\hline & Case reports & Papers & Short papers & $\begin{array}{l}\text { Rapid } \\
\text { communications }\end{array}$ \\
\hline Total & 211 & 398 & 31 & 7 \\
Rejected & $177(84 \%)$ & $217(55 \%)$ & $22(71 \%)$ & $3(43 \%)$ \\
Accepted & $12(6 \%)$ & $59(15 \%)$ & $6(19 \%)$ & $3(43 \%)$ \\
Pending & $22(10 \%)$ & $121(30 \%)$ & $3(10 \%)$ & $1(14 \%)$ \\
\hline
\end{tabular}

Table 3 Articles submitted by category

\begin{tabular}{lrrrrr}
\hline & 1994 & 1995 & 1996 & 1997 & 1998 \\
\hline Original papers & 410 & 493 & 415 & 411 & 398 \\
Case reports & 242 & 252 & 247 & 212 & 211 \\
Short papers & 14 & 48 & 51 & 40 & 31 \\
Editorials/reviews & 34 & 38 & 38 & 53 & 81 \\
Review series & 6 & 18 & 31 & 26 & 13 \\
Supplement articles & 12 & 16 & 41 & 29 & 17 \\
Case report commentaries & 3 & 7 & 11 & 7 & 7 \\
Rapid communications & - & - & 5 & 5 & 7 \\
Total & 721 & 872 & 839 & 783 & 765 \\
\hline
\end{tabular}

Table 4 Geographical distribution of submissions

\begin{tabular}{|c|c|c|c|c|c|}
\hline & 1994 & 1995 & 1996 & 1997 & 1998 \\
\hline UK & 253 & 291 & 320 & 303 & 265 \\
\hline Western Europe & 220 & 266 & 264 & 236 & 242 \\
\hline Spain & 50 & 46 & 42 & 45 & 44 \\
\hline The Netherlands & 35 & 51 & 44 & 49 & 41 \\
\hline Italy & 28 & 38 & 48 & 19 & 38 \\
\hline France & 19 & 27 & 28 & 24 & 27 \\
\hline Turkey & 15 & 13 & 14 & 22 & 20 \\
\hline Israel & 15 & 20 & 17 & 15 & 10 \\
\hline Eire & 13 & 10 & 8 & 7 & 5 \\
\hline Switzerland & 12 & 10 & 13 & 9 & 5 \\
\hline Germany & 11 & 16 & 26 & 23 & 20 \\
\hline Belgium & 9 & 17 & 12 & 11 & 10 \\
\hline Greece & 9 & 7 & 7 & 6 & 15 \\
\hline Austria & 3 & 7 & 5 & 5 & 3 \\
\hline Portugal & 1 & 3 & 0 & 0 & 2 \\
\hline Malta & 0 & 1 & 0 & 0 & 2 \\
\hline USA and Canada & 100 & 101 & 71 & 84 & 76 \\
\hline Japan & 47 & 65 & 53 & 64 & 46 \\
\hline Australasia & 32 & 38 & 31 & 60 & 48 \\
\hline Scandinavia & 27 & 36 & 32 & 39 & 36 \\
\hline Asia & 22 & 34 & 26 & 26 & 35 \\
\hline Eastern Europe & 6 & 7 & 10 & 3 & 6 \\
\hline South America & 5 & 14 & 10 & 3 & 3 \\
\hline Africa & 5 & 7 & 4 & 4 & 3 \\
\hline Middle East & 4 & 13 & 5 & 9 & 5 \\
\hline
\end{tabular}

new review series on lung infections ${ }^{11}$ and genetics, ${ }^{12}$ in addition to a supplement on sleep disordered breathing ${ }^{13}$ and important articles on coal mining and COPD. ${ }^{14}{ }^{15}$ The Year in Review supplement ${ }^{16}$ also seems to have been well received by the respiratory community. The letters section of the journal continues to be a forum for active debate and we would encourage people to send us their opinions on articles and editorials that we publish.

Overall, 1998 was a very successful year for Thorax. We would like to take the opportunity to thank the associate editors for maintaining the high standard of the journal and the excellent support from the BMJ Publications staff, Elizabeth Stockman who has provided technical editing to a consistently high standard despite relocating in Bermuda and Rachel Orme who has run the editorial office superbly well despite the foibles of the executive editors. We would also like to thank the Year in Review editors and contributors for producing the goods yet again and the members of the advisory board and referees whose vital contribution is gratefully acknowledged on page 94 . Most of all we thank the contributors for continuing to send high quality work to Thorax. We appeal to researchers around the world: send us your papers, we will give you a quick review and, if accepted, your paper is likely to be widely cited.

A J KNOX J BRITTON Executive Editors

1 Knox AJ, Britton JR. Annual Report October 1996 to September 1997. Thorax 1997;52:1023.

2 Britton JR, Knox AJ. Thorax: from the new Editorial Office. Thorax 1996;51:561.

3 Britton JR, Knox AJ. Annual Report October 1995 to September 1996. Thorax 1996;51:1177.

4 Joint Tuberculosis Committee of the British Thoracic Society. Chemotherapy and management of tuberculosis in the United Kingdom: recommendations 1998. Thorax 1998;53:536-48. 
5 Lung Cancer Working Party of the British Thoracic Society Standards of Care Committee. BTS recommendations to respiratory physicians for organising the care of patients with lung cancer. Thorax 1998;53(Supp 1):S1-S8

6 British Thoracic Society. BTS guidelines for the management of chronic obstructive pulmonary disease. Thorax 1997;52(Suppl 5):S1-S28.

7 British Thoracic Society, et al. The British guidelines on asthma management: 1995 review and position statement. Thorax 1997;52(Suppl 1):S1-S21.

8 British Thoracic Society. Current best practice for nebuliser treatment. Tho$\operatorname{rax}$ 1997;52(Suppl 2):S1-106.

9 Rogers DF, Laurent GJ. New ideas on the pathophysiology and treatment of lung disease. Thorax 1998;53:200-3.
10 Britton JR, Weiss ST. Health effects of passive smoking: introduction. Tho$\operatorname{rax} 1997 ; 52: 904$

11 Hill S. Lung infections: introduction. Thorax 1998;53:57.

12 Britton J, Hopkin J. Genetics and pulmonary medicine: introduction. Thorax 1998;53:388.

13 Fleetham JA, ed. The cardiovascular implications of sleep disordered breathing. Thorax 1998;53(Suppl 3):S1-S54.

14 Rudd R. Coal miners' respiratory disease litigation. Thorax 1998;53:337-40.

15 Coggon D, Taylor AN. Coal mining and chronic obstructive pulmonary disease: a review of the evidence. Thorax 1998;53:398-407.

16 Hendrick DJ, Mitchell DM, eds. 1998 Year in Review: selected topics in respiratory medicine from 1997. Thorax 1998;53(Suppl 2):S1-S72. 